\title{
Malignant Melanoma of Unknown Primary Site Simulating A Salivary Gland Neoplasm
}

\author{
Tükürük Bezi Neoplazmını Taklit Eden Primer Yerleşimi Bilinmeyen \\ Malign Melanoma
}

\author{
Kiran AGARWAL, Sonal JAIN, Jasmita DASS, Manoj ANDLEY \\ Department of Pathology, Lady Hardinge Medical College, NEW DELHI, INDIA
}

\begin{abstract}
Malignant melanoma with its varied clinical presentations and histomorphological patterns is a perplexing problem both for the diagnosticians and clinicians. A small proportion of melanomas present with metastatic tumors with unknown primary sites and at these sites they mimic the more common primary neoplasms. We hereby report a case of malignant melanoma presenting as a submandibular lump in a 40 year old female. This lump was present for six months and was rapidly increasing in size. On cytology it was diagnosed as salivary gland neoplasm.
\end{abstract}

Key Words: Melanoma, Salivary gland neoplasms

\section{öz}

Çeşitli klinik prezentasyonları ve histomorfolojik paternleri ile malign melanoma, hem tanı koyanlar, hem de klinisyenler için kafa karıştıran bir sorundur. Melanomların küçük bir kısmı primer yerleşimi bilinmeyen metastatik tümörler olarak ortaya çıkar ve bu alanlarda daha sık görülen primer neoplazmları taklit eder. Burada 40 yaşındaki bir kadın hastada submandibuler bir yumru olarak ortaya çıkan bir malign melanom olgusunu sunuyoruz. Altı aydır bulunan bu yumrunun boyutu hızla artıyordu. Sitolojide tükürük bezi neoplazmı tanısı konuldu.

Anahtar sözcükler: Melanom, Tükürük bezi neoplazmları

\section{INTRODUCTION}

Malignant melanoma with its myriad histological patterns and varied manifestations is a perpetual diagnostic problem. This problem becomes even more complex when it presents as a metastatic lesion with no known primary site. Melanomas of unknown primary site account for $1-8 \%$ of all melanomas in different series (1-7). Lymph node metastases account for nearly two third of these cases in most of the series with axillary lymph nodes being the most common site. Subcutaneous and visceral metastases account for the remaining. We hereby report a case of malignant melanoma metastatic to subcutaneous tissue with unknown primary masquerading as submandibular salivary gland neoplasm.

\section{CASE REPORT}

A 40-year-old female presented with a mass in the submandibular region for 6 months which was rapidly increasing in size. On examination there was a large mass measuring $6 \times 5 \times 5 \mathrm{~cm}$ in size in the submandibular region

Received : 15.10 .2009

Accepted : 04.04.2010 which was nontender and free from overlying skin and underlying structures. There was no lymphadenopathy and no liver or spleen enlargement was found on abdominal examination. CT scan of the abdomen and chest was unremarkable. A clinical diagnosis of submandibular salivary gland neoplasm was made.

Fine needle aspiration cytology from this mass yielded highly cellular smears with presence of predominantly dispersed cell population and few cohesive clusters of round to polygonal to plasmacytoid cells. These cells had moderate amount of pale basophilic cytoplasm, round to oval monotonous-looking nuclei with inconspicuous nucleoli. Few cells showed prominent nucleoli and some mitotic figures were also seen (Figure 1). A cell block prepared from the aspirated material showed polygonal to round cells with a moderate amount of pink cytoplasm and a single nucleus with prominent nucleoli in some cells. Considering the site and morphology, a diagnosis of malignant myoepithelioma was considered and an urgent excision was advised.

Correspondence: Sonal JAIN

Department of Pathology, Lady Hardinge Medical College,

NEW DELHI, INDIA

E-mail: sonalmalhotra80@gmail.com Phone: +09910719983 
Meanwhile CT scan of the head and neck was done which revealed that the mass extended to the tail of the parotid while the submandibular salivary gland was unremarkable. The patient was taken up for surgery and intraoperatively the mass was found to be infiltrating the muscle and reaching the tail of the parotid. However, the submandibular salivary gland was not related to the mass. The mass was excised and sent for histopathological examination. It measured $6.5 \times 5 \times 4 \mathrm{~cm}$ with a bosselated outer surface and the cut surface showed large areas of haemorrhage and necrosis (Figure 2). H\&E stained sections from the tumor showed tumor cells arranged in the form of nests and lobules (Figure 3). Cell morphology was the same as seen in the cell block (Figure 4). Few areas revealed brown- to blackcolored pigment that stained positive for Masson's Fontana, thus confirming that this pigment was melanin. Extensive sampling showed intracytoplasmic pigment in many cells. In

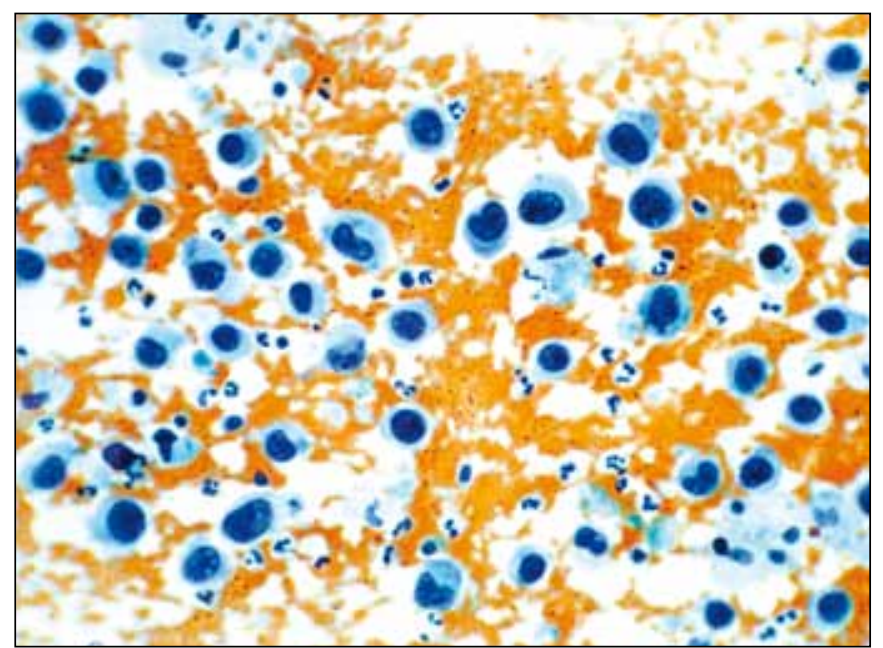

Figure 1: Giemsa stained cytology smears showing monotonous looking dispersed cell population with some cells with eccentric nuclei (x400).

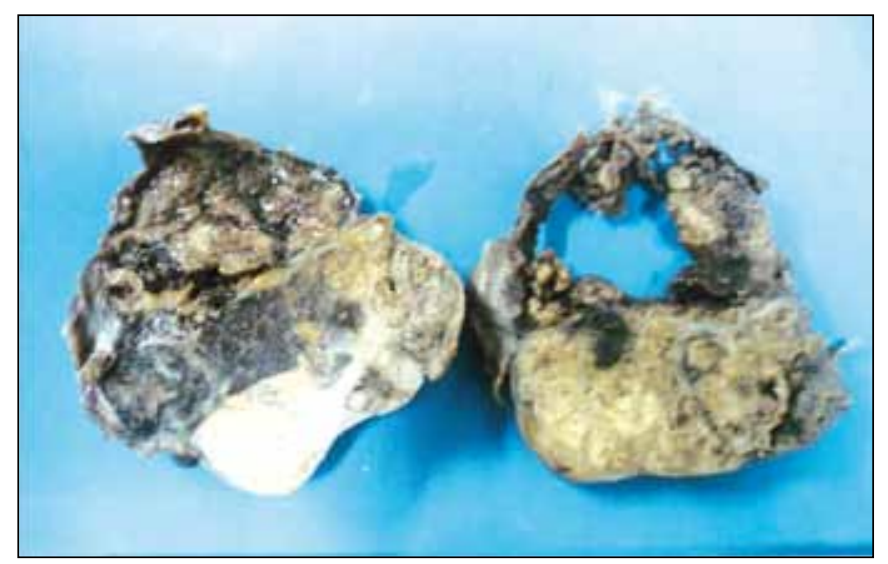

Figure 2: Mass measuring $6.5 \times 5 \times 4 \mathrm{~cm}$ with large areas of haemorrhage and necrosis. view of these findings, a differential diagnosis of malignant melanoma and myoepithelial carcinoma with melanocytic differentiation was considered and immunohistochemistry was used to differentiate the two. The tumor was strongly positive for S100 and HMB 45. It was negative for Calponin, Smooth muscle actin and Cytokeratin thus ruling out myoepithelial carcinoma. More sections were taken to look for presence of salivary gland or lymph node. No lymphoid tissue could be delineated and the adherent salivary gland was unremarkable (Figure 4). A detailed history was taken and complete clinical examination of the patient was carried out including all mucosal sites, skin and ocular examination to look for a possible primary site. The complete systemic examination was unremarkable, thus giving a final diagnosis of malignant melanoma metastatic to subcutaneous tissue with unknown primary site.

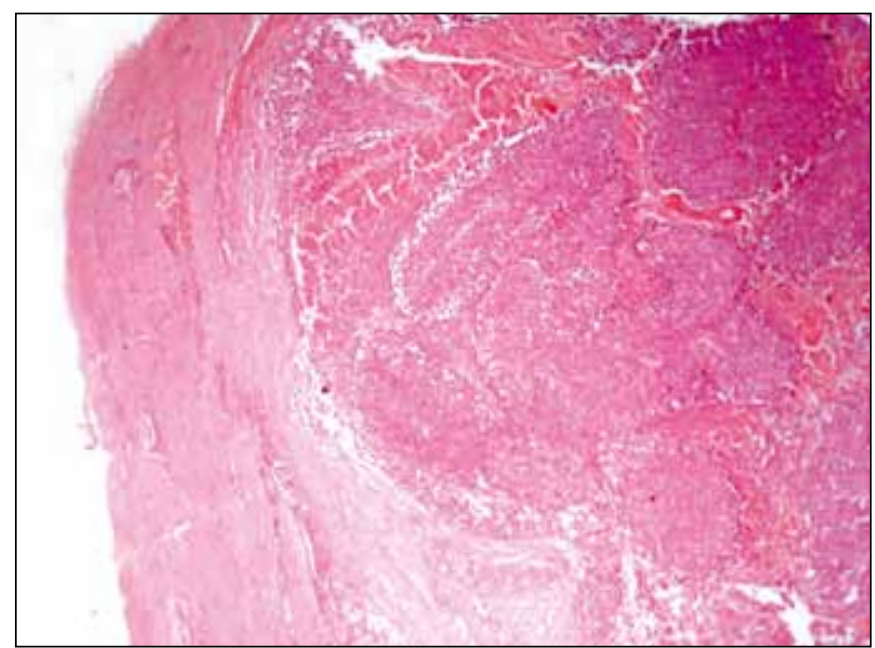

Figure 3: H\&E stained section showing low magnification (x100).

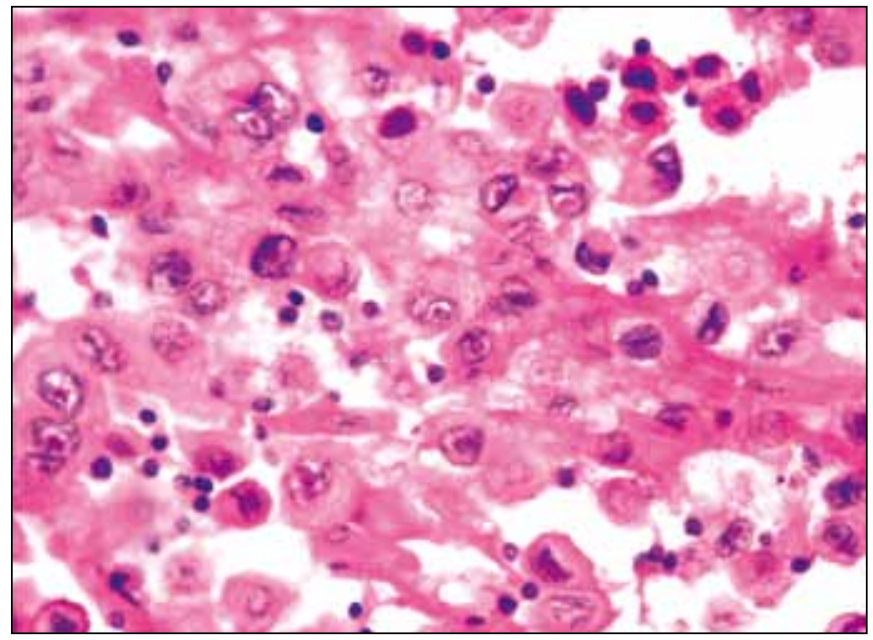

Figure 4: $H \& E$ stained section showing prominent nucleoli and occasional binucleated cells $(\mathrm{x} 400)$. 


\section{DISCUSSION}

Metastatic melanoma with its variable morphological features is a great histopathological mimicker and may be confused with tumors of nearly all lineages. Various superficial soft tissue tumours with epithelioid and/or spindle cells or with pigment can mimic it. The rare balloon cell and signet ring cell melanoma is a mimicker of primary or metastatic carcinoma and the desmoplastic variant is often misdiagnosed as benign mesenchymal lesion. Lymph node metastasis of melanoma may raise the possibility of interdigitating reticulum cell tumour or anaplastic large cell lymphoma $(8,9)$.

This problem becomes more complex when it presents at unusual sites with unknown primary sites (MUP). Lymph nodes have been found to be the most common site of MUP in most studies. Axillary lymph nodes are the most common followed by inguinal and cervical nodes (4). Schlagenhauff et al found cutaneous/subcutaneous metastases to be more frequent, accounting for more than half of all MUPs in a series including 3258 melanoma patients (2). The prevalence of solitary lesions of melanoma confined to dermal or subcutaneous tissue has been reported to be $0.51 \%, 0.63 \%$ and $0.92 \%$ in three large series $(2,4,5)$. The sites included the head and neck, upper extremity, lower extremity, and trunk.

These tumors were extensively investigated for the first time by Das Gupta et al in a series of 47 patients. The criteria proposed by this group for the diagnosis of melanoma of unknown primary have been universally applied till now. According to these criteria, history of previous orbital exenteration and presence of a mole, birth mark, freckle, chronic paronychia, or other skin lesions previously excised, cauterized or desiccated has to be excluded for a diagnosis of MUP. The authors also proposed to examine patients thoroughly including ophthalmoscopy and examination of the anogenital region (1).

Several studies have reported worse prognosis for patients with MUPs (10), while others have reported better $(2,6,11)$ or similar survival rates $(3,7)$. With regard to isolated subcutaneous masses, Schlagenhauff et al reported a 5 year survival of $83 \%$ (2). Anbari et al described 3 patients with isolated subcutaneous nodules, all 3 of which were alive after 8 years (4), Bowen et al reported an 8-year survival rate of $83 \%$ (5) which is higher than expected for Stage III (13-50\%) or Stage IV disease (5-17.9\%). Our patient is well after 15 months of follow-up.

Several etiologies for MUP have been proposed including 1) an antecedent unrecognized, spontaneously regressed melanoma (12) 2) a previously excised clinically and/or histologically misdiagnosed melanoma, 3) a concurrent clinically unrecognized melanoma, and 4) de novo malignant transformation of an errant melanocyte at a lymph node or visceral site or melanocytes associated with deeper appendageal structures (1).

In conclusion, malignant melanoma is a difficult diagnosis to make particularly when the primary site is not known. Since it is an aggressive tumor, the importance of timely diagnosis is unquestionable. A high index of suspicion, extensive sampling to look for melanin pigment and appropriate immunohistochemistry are the keys to accurate diagnosis.

\section{REFERENCES}

1. Dasgupta T, Bowden L, Berg JW: Malignant melanoma of unknown primary origin. Surg Gynecol Obstet 1963, 117: 341-345

2. Schlagenhauff B, Stroebel W, Ellwanger U, Meier F, Zimmermann C, Breuninger H, Rassner G, Garbe C: Metastatic melanoma of unknown primary origin shows prognostic similarities to regional metastatic melanoma: recommendations for initial staging examinations. Cancer 1997, 80:60-65

3. Giuliano AE, Moseley HS, Morton DL: Clinical aspects of unknown primary melanoma. Ann Surg 1980, 191:98-104

4. Anbari KK, Schuchter LM, Bucky LP, Mick R, Synnestvedt M, Guerry D 4th, Hamilton R, Halpern AC: Melanoma of unknown primary site: presentation, treatment, and prognosis--a single institution study. University of Pennsylvania Pigmented Lesion Study Group. Cancer 1997, 79:1816-1821

5. Bowen GM, Chang AE, Lowe L, Hamilton T, Patel R, Johnson TM: Solitary melanoma confined to the dermal and/or subcutaneous tissue: evidence for revisiting the staging classification. Arch Dermatol 2000, 136:1397-1399

6. Chang P, Knapper WH: Metastatic melanoma of unknown primary. Cancer 1982, 49:1106-1111

7. Reintgen DS, McCarty KS, Woodard B, Cox E, Seigler HF: Metastatic malignant melanoma with an unknown primary. Surg Gynecol Obstet 1983, 156: 335-340

8. Zelger BG, Steiner H, Wambacher B, Zelger B: Malignant melanomas simulating various types of soft tissue tumors. Dermatol Surg 1997, 23: 1047-1054

9. Lodding P, Kindblom LG, Angervall L: Metastases of malignant melanoma simulating soft tissue sarcoma. A clinico-pathological, light- and electron microscopic and immunohistochemical study of 21 cases. Virchows Arch A Pathol Anat Histopathol 1990 417:377-388

10. Pack GT, Gerber DM, Sharnagel IM: End results in the treatment of malignant melanoma. A report of 1190 cases. Ann Surg 1952, 136: 905-911

11. Cormier JN, Xing Y, Feng L, Huang X, Davidson L, Gershenwald JE, Lee JE, Mansfield PF, Ross MI: Metastatic melanoma to lymph nodes in patients with unknown primary sites. Cancer 2006, 106:2012-2020

12. Smith JL Jr, Stehlin JS Jr: Spontaneous regression of primary malignant melanomas with regional metastases. Cancer 1965, 18 : 1399-1415 